\title{
THE EFFECT OF METACOGNITIVE STRATEGY ON STUDENTS' READING COMPREHENSION AT SMK SWASTA YAPIM MEDAN
}

\author{
Ummi Kalsum Pasaribu ${ }^{1}$, Harton Badia Simanjuntak ${ }^{2}$, \\ Alvin Alvero ${ }^{3}$, and Nurmahyuni Asrul ${ }^{4}$ \\ ummiborpas@gmail.com ${ }^{1}$ \\ hartonsimanjuntak@gmail.com ${ }^{2}$ \\ alvin.skyhunt@gmail.com ${ }^{3}$ \\ nurmahyuniasrul@unprimdn.ac.id ${ }^{4}$
}

Universitas Prima Indonesia

\begin{abstract}
The research objective was to find out the effect significantly from the implementation of the Metacognitive Strategy on reading comprehension of the students. In this research, The students of SMK Swasta Yapim Medan was chosen as the sample in this research.In this research, researchers applied the experimental research. This research was done by applying the experimental group (applying the Metacognitive Strategy) and in the controlled group (without applying the Metacognitive Strategy) by using quantitative approach. The sample used by the researchers in this study was 72 students. 35 students were chosen as the sample in the experimental group. From the data it was known that the total score of the students in the experimental group after conducting the post-test was 2,714. After that the researchers found out that the students' mean score was 77.54. There were 37 students in controlled group. The total scores after doing the post-test session in the controlled group was 2.526. The mean score of the students was 68.27. The researchers found out the independent sample from the t-test. After that the researchers found out that the t-table was lower than the t-test $(\mathrm{t}$-table $=3.563<\mathrm{t}$-test $=7.693)$. Meanwhile it was found out that the significance (p) was 0.001. The significance showed that $0.001<0.005(\mathrm{p}<0,005)$. After conducting the research done by the researchers, it was known from the data that $\mathrm{H}_{1}$ can be accepted and $\mathrm{H}_{0}$ is rejected. The research findings were significant because $p<0.005$. From the data of the result as explained above, the researchers gave a conclusion that after applying the Metacognitive Strategy on the students' reading comprehension, it had significantly affected the reading comprehension of the students.
\end{abstract}




\section{INTRODUCTION}

Reading comprehension is very important for students especiall the students who learn English at vocationals school. Reading comprehension can be understood as the ability of the readers to get information after doing interpretation from the text that the students have read. Mean while, reading comprehension is very importatn on academic aspects. Students who have read a text must be able to explain or retell the content of the text that they have read before. The students can get many new English vocabularies after reading a text. From the reading comprehension, it can improve the students' knowledge. Students who have read more texts can get many references that can be used in their daily needs. By mastering reading comprehension, the students can develop their skills especially in English Language.

Reading is the process to get information from the text that has been done by the readers. After reading a text, the readers can enrich their knowlede, especially from many kinds of text. The readers can get many ideas after reading a text. Educators have assumed that rading comprehension can lead the students to get academic success in their lives (Jennifer, Lindsey, and Ulana, 2010). The students should be able to master the reading comprehension as it is one of the basic skills that sould be mastered by the students. The student can gain more understanding from many aspects of knowledge after reading a text. There are many information from this world that can be got from the reading comprehension. In 2005, Tierney stated that as the basic goal, the students must mater the reading comprehension. The students can get many knowledge from the reading comprehension. Then it can be said that the students can develop their thinking skills to understand what the students have read from the text. Meanwhile reading comprehension was defined as the process of thinking that had been used to get the meaning. The people can get more information after reading a text (Block, Gambrell, and Pressley, 2002). The readers should know the good instructions on reading comprehension.

One of appropriate strategy in developing reading comprehension is Metacognitive strategy. This strategy is really important in developing the reading comprehension. From many resources it had been known that there are many positive correlation on students who appllied metacognitive strategy in reading comprehension. Metacognitive had given many positive aspects in developing the reading comprehension. There were many students that can be done, and from the 
studies it was found out that there are many positive benefits of use the metacognitive stratey. It can develop the awareness of students in the process of the reading comprehension. It can also give positive impact and ability to students when the students read the text and follow the instructional method that generated the high levels of the involvement of the students. Then it can require the substantial cognitive and the activitiy of metacognitiy (William and Atkins, 2009:39). As an addition, Baker and Brown (1984), it was cited by McKeown and Back (2009:7-8), there is an explanation that there was an investigation about the correlation between effective reading and metacognitive ability. From the studies, it was concluded that there were two dimensions of the ability of metacognitive, they were the knowledge of metacognitive, the awareness of metacognitive, and cognition regulation. It had been stated that there were correlation between cognitive resources and the ability when the readers do the reading comprehension according to the situation when they were reading a text.

Chammot and O'malley (1996) stated that the training of metacognitive stratey consist of threee components. Those components consist of planning, monitoring, and evaluation. When doing a plan, the teacher must ask the students to overview the main ideas and the concepts from the text. In the monitoring session, the teachers must do the checking on the comprehension of students during reading comprehension session. When doing the checking, the teacher will check the students' comprehension. It was done by giving questions to the students. The teachers did it when the students were doing the reading comprehension. Lastly, when doing the evaluation, the teachers will give questions to the students during the reading comprehension done by the students. From that step, the students must be able to reflect what they have got from the task that the teachers have given to them. Sari (2017) had done a study. This study was about the teaching of metacognitive strategy instruction according to the Communicative Academic Language Learnign Approach (CALLA). After doing the study, it was found out that there were three components of metacognitive strategy that had been focused in this study.

Ifticha Saniyati Shobiroh (2016) had conducted a research. The topic was about The Metacognitive Strategy Implementation in Improving the Reading Comprehension of the students at Grade Eleven of MA Karanggde in school years 2016/2017. In this research, the researcher applied Classroom Action Research (CAR) method. After doing the research, the researcher concluded the students' reading comprehension at grade eleven of MA Karanggede in school years 2016/2017 had been improved after applying the metacognitive strategy in the learning process. This research had been done into 3 cycles. Different themes of personal letter material in each cycle had been applied when doing this research. In doing the research, the reseracher gave the students a material. The students were asked by the researchers to read a material that had been prepared before. After doing that, the students read the material that had been given by the 
researchers. After that the application of metacognitive strategy that had been designed by the reasearcher in the teaching and learning processes was given to the students.

Next there was a research about the use of the Metacognitive Reading Strategies to the students of semester five of the English department students in school years 2015/2016. Shella Arini already did this research. After doing a research, there was a conclusion that the level of specific strategies had been favored by the students. Next the researcher found out that the average score from all categories had been calculated to find the mean scores of the students. After teaching the reading comprehension to the students in the classroom by using the metacognitive strategy, the researchers got the data. The researchers could conclude that the study had revealed the metacognitive strategy level in reading comprehension. In another words, it can be conluded that it was moderatedly being applied by the learners in this study.

As an addition, the researcher also read a journal. After reading the journal, the researchers got the data that there was an effect of the use of Metacognitive strategy training on the students' reading comprehension at English Department in a vocational technology college. Then from the data it can be stated that awareness of Metacognitive in the learning process could increase the students' reading comprehension. This research was done by Hingyuan. From this research, there was a conclusison. The researcher concluded that after using the Metacognitive strategy in the learning process, it could help the students to make a plan, monitor, and evaluate the progress of reading comprehension done by the students. For English Department, The students feel more necessary with the efficiency of reading comprehension by applying Metacognitive strategy. Although the students are not aware of the use of the strategy, the students were able to use non contributory of strategies in reading comprehension in their daily lives.

Meanwhile the researchers also read a journal, entitled: The effect of metacognitive strategy training on reading comprehension and metacognitive awareness of English majors in a vocational technology college, written by Xingyuan Wan (2014). The resarcher concluded that Metacognitive strategy can assist the students' plan, monitor and evaluate the students' reading process. Then Metacognitve strategy playes the a significant role on students' reading comprehension. Next trainings that conducted by using verbal reporting method can enable the students to do performance better and the students can learn more. The main poin to get success on the application of the metacognitive strategy was that the students were taught by applying metacognitiveg strategy, so the students could become independent learners.

The writers also read an international journal, written by Yahya Otman, Zamri Mahamud, and Noradinah Jaidi (2014. The research entitled "The Effects of Metacognitive Strategy in Reading Expository Text. According to the result of the research, it can be stated that applying metacognitive strategy can help the 
students to be more active in the learning process, especially in reading comprehension. Then the students were more motivated and have higher confidence. Metacognitive strategy could encourage the students based on the reading comprehension that they learned

Teachers were suggested to apply the effective and flexible use of the metacognitive strategy in teaching reading comprehension in the classroom. From this result, there was an investigation that had indicated the training of metacognitive strategy, who were exposed, affected the students after applying the metacognitive stratregy in reading comprehension. The researcher got the data from experimental group. The Students from the experimental group got better achievement after taught by using metacognitive strategy. This achievement was better than the achivement from the controlled group students. The students from the experimental group could achieve good instruction about how to read a text effectively and effeciently by applying the direct purpose of the improvement of the proficiency of the English reading comprehension.

The researchers had been inspired of the idea in metacognitive strategy and its rules. The researchers could propose a research according to the modified model of the training of the metacognitive strategy. There were three components of metacognitive strategy. These metacognitive strategy components had been elaborated by the researchers with orchestrating the various strategies. The researchers could enhance the orchestrating the various strategies recently of the use of the metacognitive strategy componenents. By doing the process of the raising the awarness, the students could do a program based on the application of metacognitive strategy. After doing the research, it was found out that there might be new rules in training the metacognitive strategy. It was expected that the research could support the students' reading comprehension improvements

Due to covid-19 pandemic that have been taking place, the writers were interested to conduct a research. Online learning is done due to covid-19 pandemic, so the writers were interested to do a research, especially teaching about reading comprehension. To get the first information, previously, the writers had conducted an observation at SMK Swasta Yapim Medan, at Grade Eleven in September 2020. There were 37students at grade XI. The writers got the students' average scores. The average score was 55. KKM (Kriteria Ketuntasan Minimum) at the school is 70. From the observation conducted before, it was known about students' reading comprehension ability was still poor. This finding also was supported by the English Teacher' explanation. From the data, it was known that there were students' difficulties in learning the reading comprehension in the classroom. The data were taken from the explanation of the English teacher and this data was used by the researchers.

According to the result that had been explained above, there were some functions of the use of the metacognitive strategy. One of the functions was to know the mental process of someone in the learnign process and also it was related with the management system of the processes that done by the students in 
the reading comprehension. There was a reason that had lead the reasearchers to do this research, entitled: The Impact of the Metacognitive Strategy on the Students' Reading Comprehension of SMK Swasta Yapim Medan.

According to the explanation above, the problem of the study was "Does Metacognitive Strategy affect the students' reading comprehension at SMK Swasta Yapim Medan?". The research objective was to know the effectiveness of the implementation of the Metacognitive Strategy on the students' reading comprehension at SMK Swasta Yapim Medan. In doing the researchs, the researchers only focused on the effectiveness of the implementation of the Metacognitive Strategy on the students' reading comprehension. The topic in reading comprehension was about Narrative Text for grade eleventh in academic year 2020/2021.

This study had significances theoritically and practically. Theoritically, this research can be beneficial as one of references for the next researchers who will do the next research related to the topic that was researched in this research. Practically, this research has benefits for students and English teachers at this school. For students, it is expected that the students will have better motivation in learning English, especially when the students learn about reading comprehension. As an addition, this research is also expected that the students will have more interests in improcing their English everyday. For English teachers, this research can be used as one of references when the English teachers teach English effectively. There will be more efforts for English teachers and the English teachers can be creative in designing the materials and then it will be taught to the students. After more efforts, the English teacher can guide the students to have happiness and the students will be motivated in the classroom, especially when the students are learning about the reading comprehension.

Related to the theory as presented above, the hyphotesis of the research are formulated as followed:

Ha (alternative hypotesis): The Metacognitive Strategy gave an impact significantly to the students' reading comprehension.

Ho (null hypotesis): The Metacognitive Strategy did not give an impact significantly to the students' reading comprehension.

\section{METHOD}

The researchers designed this research as an experimental design. In conducting this research, the researchers applied quantitative design. Aliaga and Gunderson (2002) in Mujis (2004:1) stated taht quantitative approach is the explanation of the phenomena. It was done by collecting the numerical data. After 
that the data are analyzed by applying a method mathematically, especially by applying statistic particularly. The researchers should collect the numerical data in quantitative research. In the research, the researcher applied data mathematically according to the method that applied. The data should be designed into numerical form.

According to Fraenkel and Wallen (2009:261) it was stated that there must be an impact in the experimental design, at least in the independent varibale and one or more in the dependent variables. Independent variables are refered frequently as the experiental group. A treatment was done to this group. Dependent variables refer to the study result. In designing this research, the researchers made two variables in this research. Firstly, variable called as independent variable (X) as Sugione had explained in his book (2006:61). It was defined that independent variable is a varibale that affects to the dependent variable. Metacognitive strategy was independent variable. Secondly, according to Sugiyono (2006:61) it was stated that dependent variable was a variable that was affected by the independent varibale. Reading comprehension was dependent in this research.

This research had been conducted at SMK Swasta Yapim Air Bersih Medan. It is located at jalan Air Bersih Medan. There were three grades in this school, fristly tenth grade, secondly eleventh grade, and thirdly twelfth grade. This research had been done to the eleventh grade students at SMK Swasta Yapim Air Bersih Medan in the school year 2020/2021 in the first semester. This research was done in December 2020. The research was done online as covid-19 pandemic is still happening till know. The research was done by using zoom application. So the researchers did this research via zoom application.

The research choose grade eleven students of SMK Swasta Yapim Air Bersih Medan as the population in the school year of 2020/2020. There were 9 classes made as population in this research. Each class consisted of 35 to 40 students. 360 students were chosen as the total population in this research. 72 students were chosen as teh sample in this research. The researchers choose 35 students as the sample in the controlled class and 37 students were chosen by the researchers as the sample in the experiemental class.

The researchers applied cluster random sampling in this research. The sample was taken from the population. Furthermore cluster random sampling was the sample from groups. It was not individual. Those samples were taken randomly selected. Selected grop had similar characterstics. To determine two classes that were used as the sample, the researchers applied cluster random sampling. The researchers randomly determined the group to be made as the experimental class. The controlled group students were taken from one class. The students from XI-TKR 1 class were chosen as the experimental class and students from XI-AV was chosen as the controlled class.

\section{Technique of Collecting Data}


According to Arikunto (2002:127) it was stated that test is the set of questions, exercises, or another instruments. It can be used as the measurements of the skills, knowledge, intelligence from indvidual or groups. In the English Language Testing, there was a test in reading comprehension. This test was applied by the researchers to measure the reading comprehension ability of the students. Written test was used by the researchers in this research. By doing this test, the researchers had known the students' mastery in reading comprehension, especially about narrative text. The researchers applied the pre-test and the posttest session to the students. The students were divided into two groups. They were the students in experimental group and students in the controlled group. After conducting the pre-test and the post-test to the students from experimental and controlled group, the researchers got the data. The researchers got the score of the students after conducting the pre-test and the post-test to the students.

\section{Data Analyzing Technique}

Several methods had been used by the researchers to get the important data to write this research. Those methods were observation, test, and documentation.

\section{Test of Pre-Requisite}

The researchers examined the normality and homogenity before determining the use of technique based on statistical analysis. To find out the data distiribution was categorized as normal or not, the normality was tested. Chisquare was applied by the researchers. There were some steps of chi-square. Firstly, it can be used to determine teh span (R), and higher score was lessened to the lower ones. Secondly, the researchers applied chi-square to determine many class intervals $(\mathrm{P})$. The researchers used a formula in this step. The step was to make the table of distribution frequency. Thirdly, the researchers used chi-square to determine the boundary of class $(\mathrm{Bk})$ from each interval of class. Fourthly, the researchers used chi-square to determine the mean score of the students, determine the variants by using a formula, and lastly by determining $\mathrm{Z}$ score.

To determine the data that categorised as homogen or not, the researchers applied homogenity test. There were some steps in this session. Firstly, determining the mean score, determining the variants (s2). It was done by using a formula. Then the reserachers determined $\mathrm{F}$. It was done by using a formula, then comparing Fvalue with Ftable $12 \alpha$ (nb-1) (nk-1) and dk = (k-1). When the Fvalue $<$ Ftable, it can be concluded that it was categorised as homogen distribution.

\section{FINDINGS AND DISCUSSION}

The researchers collected the data after doing the pre-test and post-test sessions to the students. The pre-test and post-test sessions were done to the students of XI-TKR 1 class and the students of XI-AV class. 37 students were 
chosen as the sample in the controlled class. 35 students were chosen as the sample in the controlled class. Tests were given to the students. The tests were into multiple choice questions. There were 20 multiple questions given to the students. The tests were given to the students online. It was done by sharing the link that consisted of the questions. The research did online test as covid-19 pandemic was happening when the this research was done. After doing the tests, the researchers collected teh asnwer sheets. Answer sheets were printed out. After checking the answer sheets out, the researchers got the results. The researchers got the result of students. The results were taken from the students of controlled class and experimental class. The result is explained tusing the table below.

Table 4.1.

The Students' Data in the Controlled Class and Experimental Class

\begin{tabular}{|c|c|c|c|c|c|}
\hline & \multirow{3}{*}{$\begin{array}{c}\begin{array}{c}\text { Pre-test } \\
\text { XI_TKR } 1\end{array} \\
35\end{array}$} & \multirow{3}{*}{$\begin{array}{c}\text { Pre-test_XI- } \\
\text { TKR } 1\end{array}$} & \multirow{3}{*}{$\begin{array}{c}\begin{array}{c}\text { Pre- } \\
\text { test_XI-AV }\end{array} \\
37\end{array}$} & \multirow{3}{*}{$\begin{array}{c}\begin{array}{c}\text { Post- } \\
\text { test_XI- } \\
\text { AV }\end{array} \\
37\end{array}$} \\
\hline & & & & & \\
\hline $\mathrm{N}$ & Valid & & & & \\
\hline & Missing & 0 & 0 & 0 & 0 \\
\hline \multicolumn{2}{|c|}{ Mean } & 65.49 & 77.54 & 64.86 & 68.27 \\
\hline \multicolumn{2}{|c|}{ Std. Error of Mean } & 1.671 & 1.854 & 1.754 & 1.633 \\
\hline \multicolumn{2}{|c|}{ Median } & 66 & 78 & 66 & 68 \\
\hline \multicolumn{2}{|c|}{ Mode } & 60 & 80 & 60 & 50 \\
\hline \multicolumn{2}{|c|}{ Std. Deviation } & 4.293 & 3.791 & 4.231 & 5.378 \\
\hline \multicolumn{2}{|c|}{ Variance } & 68.267 & 78.836 & 71.898 & 73.342 \\
\hline \multicolumn{2}{|c|}{ Range } & 40 & 45 & 42 & 42 \\
\hline \multicolumn{2}{|c|}{ Minimum } & 56 & 70 & 54 & 60 \\
\hline \multicolumn{2}{|c|}{ Maximum } & 78 & 86 & 72 & 84 \\
\hline \multicolumn{2}{|c|}{ Sum } & 2,292 & 2,714 & 2,400 & 2,526 \\
\hline
\end{tabular}

Pre-test and post test sessions were given to the students in the controlled group and in the experimental group. The researchers conducted the pre-test test sessions before giving the post-test session to teh students. 37 students were chosen as the sample in the controlled group and 35 students were chosen as the sample in the experimental group. The researchers took the data after conducting the pre-test to the students from controlled group and experimental class. After calculating the students' score, the total score of the students was known by the researchers. By seeing the data, the total score of the students was known. There were to categories of the total scores of the students, it came from the experimental group and controlled group. The total score was known by the researchers after doing the pre-test session. The total score of the students after doing the pre-test session was 2,292. It was known by the researchers that the mean score of the students 
was 65.49. the lowest score of the students was 40. The highest score of the students was 78. In the controlled group, the data was seen by the researchers. After doing the pre-test session in the controlled group, the researchers got the data. The total score was 2,400 . The mean score of the students was 64.86. After seein the data as presented above, it was known that the lowest score of the students was 54 and the highest score of the students was 72 .

After using the metacognitive strategy in the post-test session to the students from experimental group, the researchers got the data. The total score of the students was 2,714. The mean score of the students was 77.54. The lowest score of the students was 70 and the highest score of the students was 86 . In the research, the researchers used conventional teaching strategy in teaching reading comprehension to the students from controlled group. The total score of the students was 2,525. The mean score of the students was 78.27. The lowest score of the students was 60 and the highest score of the students was 84 .

After calculating the data of the students, then the researchers used SPSS to get the data efectively. It was found out that the mean score was increased after doing the post-test session to students who were from the experimental class. After seeing the data, it can be known that the mean score of the experiemental class students was higher than the mean score of the students from the controlled class. After doing the post-test, it was known that the mean score of students was 77.54. Meanwhile after doing post-test in the contrlled class, it was known that the mean score of the students was 68.27. The difference was 9.27. After seeing the data, it can be concluded that applying metacognitive strategy gave significant effect to the students in the experimental group. Applying metacognitive strategy was more effective to the students in the experiemental class than applying conventional teaching strategy to the students in the controlled class. It can be seen from the data that had been presented before.

\section{Data Analysis}

The researchers analyzed the data first then the hypothesis was proved. The researchers applied the t-test formula.

\section{The Test of Independent Sample}

\begin{tabular}{|c|c|}
\hline $\begin{array}{l}\text { Variance } \\
\mathrm{s} \\
\text { Equality } \\
\text { in the } \\
\text { Test of } \\
\text { Levene }\end{array}$ & $\begin{array}{l}\text { Means Equality } \\
\text { of the t-test for } \\
\text { Means Equality }\end{array}$ \\
\hline
\end{tabular}




\begin{tabular}{|c|c|c|c|c|c|c|c|c|c|c|}
\hline & \multirow[t]{2}{*}{$\mathrm{F}$} & \multirow[t]{2}{*}{ Sig } & \multirow[t]{2}{*}{$\mathrm{t}$} & \multirow[t]{2}{*}{$\mathrm{df}$} & \multirow[t]{2}{*}{$\begin{array}{l}\text { Sig. } \\
\text { (2 tailed) }\end{array}$} & \multirow{2}{*}{$\begin{array}{l}\text { The } \\
\text { Mean } \\
\text { Differ } \\
\text { ence }\end{array}$} & \multirow{2}{*}{$\begin{array}{l}\text { Standa } \\
\text { rd of } \\
\text { Error } \\
\text { Differ } \\
\text { ence }\end{array}$} & \multicolumn{2}{|c|}{$\begin{array}{l}\text { Internal } \\
\text { Confidence } \\
\text { (the } \\
\text { difference } \\
\text { was } 95 \% \text { ) }\end{array}$} \\
\hline & & & & & & & & & $\begin{array}{l}\text { Low } \\
\text { er }\end{array}$ & $\begin{array}{l}\text { Upp } \\
\text { er }\end{array}$ \\
\hline \multirow[t]{2}{*}{$\begin{array}{l}\text { Hasi } \\
1 \\
\text { belaj } \\
\text { ar }\end{array}$} & $\begin{array}{l}\text { Assu } \\
\text { ming } \\
\text { as the } \\
\text { equal } \\
\text { varian } \\
\text { ces }\end{array}$ & $\begin{array}{l}47 \\
8\end{array}$ & 254 & $\begin{array}{l}7 . \\
69 \\
3\end{array}$ & 70 & $<001$ & 9.273 & 2.613 & $\begin{array}{l}16.56 \\
4\end{array}$ & $\begin{array}{l}28.2 \\
37\end{array}$ \\
\hline & $\begin{array}{l}\text { Assu } \\
\text { ming } \\
\text { as not } \\
\text { the } \\
\text { equal } \\
\text { assum } \\
\text { ing }\end{array}$ & & & $\begin{array}{l}7 . \\
69 \\
3\end{array}$ & $\begin{array}{l}38 \\
.4 \\
58\end{array}$ & $<001$ & 9.273 & 2.613 & $\begin{array}{l}16.54 \\
7\end{array}$ & $\begin{array}{l}28.1 \\
65\end{array}$ \\
\hline
\end{tabular}

After seeing the data above, it can be statede that the degree of freedom (df) was XI-TKJ $1+\mathrm{XI}-\mathrm{AV}-2=35+37-2=70$. After seeing the table as presented above, it was known that the t-test was 7.693. It was found out that the t-table 3.563 was lower then the t-test $=7.69$. according to the data as presented above, it can be known that that the-test was higher than the t-table. Meanwhile the significance (p) can be seen that $0.05(\mathrm{p}<0.05)$. After doing this research, the researchers concluded that $\mathrm{H} 1$ could be accepted and Ho was rejected in this research. The researchers stated that this research was significant as $p<0.05$. According to the data as presented before, the researchers stated that hyphotesis can be accepted. The students' reading comprehension from the experimental group had better achievement after taught by using the metacognitive strategy. It was better than the students' reading comprehension from the controlled group after taught by using the conventional teaching strategy.

\section{The Findings of Research}

After conducting the research, There were some findings:

1. It can be concluded that there was an effect significantly on the reading comprehension of the students in the experimental class after taught by applying Metacognitive Strategy. From the data presented before it can be known that teaching reading comprehension by applying Metacognitive Strategy is more effective than teaching reading comprehension by applying conventional strategy. The difference of mean score at controlled group and experimental group after doing post-test is the reason to 
conclude that teaching reading comprehension to the students by applying Metacognitive Strategy is really effective.

2. The result of this research can conclude that the t-test was higher than the t-table $(7.693>3.563)$. The significance $(p)$ was 0.001 . It was lower than 0.005. It can be concluded that $\mathrm{H} 1$ was accepted and Ho was rejected. At final, Applying Metacognitive strategy is really effective in teaching students' reading comprehension. Metacognitive strategy had affected the students' reading comprehension.

\section{CONCLUSIONS AND SUGGESTIONS}

In accordance with the research findings as presented in this research, the researchers could give the conclusion. Firstly, it was known that the mean score of the students was almost same in the pre -test in the experimental group and controlled group.

After giving the post-test session to the students in the experimental group, it was known that the mean score of the students was higher thatn the mean score of the students in the controlled group. Thirdly, There was different achievement in reading comprehension after the students were taught by applying metacognitive strategy. The reading comprehension achievement of the students from the controlled group and the experimental group was different. The students in the controlled group were taughy by using conventional teaching strategy. The students in the experimental group were taught by using the metacognitive strategy. After knowing the result of the level of the significance of ANCOVA, it can be seen that it was lower than 0.005. additionally, the improvement result in the experimental calass was 12.05. It had shown thatn it was higher than the achievement in the controlled class that was 3.41. It is expected that this research finding can imply the implementation of metacognitive strategy on the teaching reading comprehension. This research had shown the data that can be used to promote the implementation of the metacognitive strategy in improving the students' reading comprehension. After seeing the data from this research, it is expected that the metacognitive strategy can be recommended as one of good strategies in teaching reading comprehension. The English teachers can apply the metacognitive strategy in teaching reading comprehension in the classroom.

After knowing the data as presented above, the researchers gave some suggestions. Firstly, for English teachers, metacognitive strategy is very appropriate to be applied in teaching reading comprehension in the classroom. Furthermore, the metacognitive strategy is suggested by the researchers to the English teachers to be applied in the learning process, especially when the English teachers teach reading comprehension. The Metacognitive strategy can be applied in the learning process to increase the students' reading comprehension. Secondly, a suggestion for the students, the students can apply metacognitive strategy in the learning process especially when the students learn ebout reading comprehension. From this activitiy the students alwo can understand the contents, contexts, and 
the information specifically, about the topic, main idea, and many more. Thirdly, for next researchers,it is hoped that there will be more researchers who will conduct the next research especially about the use of metacognitive strategy in the reaing comprehension.

\section{REFERENCES}

Aguilera, G., Illesca, C., Montecinos, C., Sandoval, V., Navarro, C. \& Whipple, K. 2016. MetacognitiveListening Strategies: Exploring theeffects of implicit metacognitiveinstruction on intermediatesecond/foreign English languagelearners at Universidad de Chile. Published Thesis: Universidad de Chile. From http://repositorio.uchile.cl /bitstream/handle/2250/137573/ Metacognitive-listeningstrategies. pdf?sequence $=1$

Al-Alwan, Ahmed F. (2009). "The Effect of Using Metacognition Reading Strategies on the Reading Comprehension of Arabic Texts". IJAES - Vol. 13 No. 1.

Aliaga, M. and Gunderson, B. 2002. Interactive Statistics. Thousand Oaks: Sage

Anderson, Neil J. (2002). The Role of Metacognition in Second Language teaching and Learning.Washington: ERIC Clearinghouse onLanguage and Linguistic.

Arini, Shella. (2018). "Metacognitive Reading Strategies Used by the Fifth Semester of English Teacher Education Department Students in Academic Year 2015-2016". Thesis. Univrsitas Islam Negeri Sunan Ampel.

Blachowicz, C., \& Ogle, D. (2001). Reading Comprehension. New York, NY: The Guilford Press.

Block, C., Gambrell, L., \& Pressley, M. (2002). Improving Comprehensioninstruction rethinking research,theory, and classroom practice. San Francisco, Ca: Jossey - Bass.

Brown, H. D. (2001). Teaching by Principles an Interactive Approach to Language Pedagogy (2nd Ed.). New York: Addison Wesley Longman,Inc.

Cameron S., and Myers, S. (2013). Comprehending Functional Text: Instruction, Practice, Assesment. Quincy, IL: Mark Twain Media, Inc

Chamot, A. U., \& O’Malley, J. M. (1996). The cognitive academic language learning approach: A model for linguistically diverse classrooms. The Elementary School Journal, 96, 259-273. doi:10.1086/461827

Fraenkel, Jack R. And Norman E. Wallen. (2009). How to Design and Evaluate Research in Education. New York. McGraw-Hill Companies.

Gambrell, L. B. Pressley, M. (2002). Improving comprehension instruction: Rethinking theory, research and classroom practices. San Francisco: Jossey-Bass.

Harmer, J. (2001). The Practical of English Language Teaching. England:Pearson Education Limited. 
Hacker, D. J., \& Niederhauser, D. S. (2000). Promoting Deep and Durable Learning in the Electronic Classroom. Principles of Effective Teaching in On-Line Classrooms. New Directions for Teaching and Learning, 84, 5364.

Klinger, Janette K and Sharon Vaughn. (2007). Teaching Reading Comprehension to Student with Learning Difficulties. New York: The Guildford Press.

McKeown and Back. 2009. The Role of Metacognition in Understanding and Supporting Reading Comprehension. In Hacker. D.J, Dunlosky. J and Graesser. A.C. (Eds.), Handbook of Metacognition in Education, 39. New York. Taylor \& Francis.

Papaleontiou-Louca, E. (2008). Metacognition and Theory of Mind. Newcastle: Cambridge Scholars Pub.

Sari, Melina. (2017). Modifying Metacognitive Strategy Instruction Based Cognitive Academic Language Learning Approach. Unpublish Thesis. Universitas Lampung.

Scrhaw, G. and Mochan D. (1995). Metacognitive Theories. Nebraska: Educational Psychology Papers and Publications

Shobiroh, Ifticha Saniyati. (2007). "The Use of Metacognitive Strategy to Improve the Students' Reading Comprehension"(A Classroom Action Research of the Eleventh Grade Students of MA Karanggede 2016/2017). Thesis. IAIN Salatiga.

Tierney, J. (2005). Reading Strategies and Practices. (Sixth ed.). Boston:Pearson Education, Inc.

Wang, Xingyuan. (2014). "The Effect of Metacognitive Strategy Training on Reading Comprehension and Metacognitive Awareness of English Majors in a Vocational Technology College". World Transactions on Engineering and Technology Education. Vol.12, No.1, 2014.

William and Atkins. 2009. The Role of Metacognition in Teaching Reading Comprehension to Primary Students. In Hacker. D.J, Dunlosky. J and Graesser. A. C. (Eds.), Handbook of Metacognition in Education. New York. Taylor \& Francis.

Yuko, I. (2009). Metacognition Awareness and Strategy use in Academic English reading Among Adult English As A Second Language (ESL) students. Unpublished doctoraldissertation, University of SouthernMississippi, U.S.A 